\title{
GUILHERME DE OCKHAM E O JUSNATURALISMO
}

\section{Paulo Henrique Faria Nunes ${ }^{1}$}

\section{Resumo}

O direito natural tem sua origem mais remota na Antiguidade, quando serviu de instrumento de legitimação do poder de Roma. Na Idade Média, filósofos ligados à Igreja se apropriaram do jus naturale e o adaptaram àquele momento de disputa de poder entre o papa e os governantes seculares. Este artigo analisa os elementos do jusnaturalismo presentes na obra de um expoente da escolástica tardia, Guilherme de Ockham. Para um clérigo na Idade Média, suas ideias sobre razão, liberdade, igualdade, propriedade e limites do poder dos governantes, igualdade, sobretudo no contexto em que foram escritas, são muito avançadas e ajudam a compreender a transição do jusnaturalismo teológico para o secular. No que concerne ao autor em destaque, a análise se concentra em seu último grande trabalho político: De imperatorum et pontificum potestate.

Palavras-chave: Direito Natural; Guilherme de Ockham; direitos fundamentais; política; poder.

\section{INTRODUÇÃO}

O constitucionalismo, movimento com vistas ao estabelecimento de uma norma fundamental que disciplina o funcionamento dos órgãos estatais e limita o exercício do poder político, é um fenômeno relativamente novo. Conquanto a Magna Carta (1215) seja frequentemente lembrada como um marco na definição de limites aos governantes, ela foi um fato isolado em sua época.

A popularização das Constituições só ocorreu a partir do século XVIII, inspirada nas doutrinas liberais e nas grandes revoluções (Americana e Francesa). Não obstante, a discussão relativa à legitimação do poder não é nova e está intimamente ligada ao direito natural da Idade Média. Além de Tomás de Aquino (1225-1274), autores menos lembrados como Guilherme de Ockham (1280?-1349?), João de Paris (1270-1306) e Marsílio de Pádua (1275-1342) se debruçaram sobre o assunto quando das disputas entre os poderes secular e eclesiástico na Idade Média e são fundamentais para a compreensão da noção de jusnaturalismo moderno e soberania popular.

Este artigo é dedicado ao jusnaturalismo e à análise de alguns de seus principais elementos na obra política de Guilherme de Ockham. O texto está dividido em duas partes: na primeira, apresentam-se considerações preliminares sobre o jusnaturalismo, indispensáveis à consecução do objetivo proposto; na 
seguinte, confere-se especial atenção ao autor em destaque no título. A segunda parte traz aspectos históricos sobre a vida e a obra de Guilherme de Ockham, uma introdução ao seu pensamento, e, por último, uma análise dos elementos do jusnaturalismo presentes em sua derradeira obra política: De Imperatorum et Pontificum Potestate (Sobre o poder dos imperadores e dos papas) - e os elementos do jusnaturalismo ali encontrados.

Na elaboração deste artigo, recorreu-se à análise da obra de expoentes da filosofia política (Tomás de Aquino, Grotius, Hobbes, Locke), a estudos anteriores de ciência política e teoria do estado relacionados ao tema e, evidentemente, aos escritos de Guilherme de Ockham e seus comentadores.

\section{JUSNATURALISMO: ASPECTOS GERAIS}

Antes da apresentação de qualquer conceito ou definição, esclarece-se que este trabalho adota a linha de pensamento de autores que admitem a existência de princípios jusnaturalistas na Baixa Idade Média e na Antiguidade, sobretudo a partir da compilação do Corpus Iuris Civilis, promovida pelo imperador Justiniano I no séc. VI (Kritsch, 2002; Russel, 2002). Encontra-se no Título II (De Iure Naturale, Gentium et Civili) da Instituta, um dos quatro livros que integram o Corpus Iuris Civilis, a seguinte definição de direito natural (1889, p. 6):

Derecho natural es el que la naturaleza enseño a todos los animales. Mas este derecho no es privativo del género humano, sino de todos los animales que nacen en el cielo, en la tierra y en el mar. De aquí proviene la unión del macho y de la hembra, que llamamos matrimonio; de aquí la procreación y la educación de los hijos: porque vemos que también los demás animales se rigen por el conocimiento de este derecho.

O direito natural admite a existência de valores universais que dizem respeito a todos os seres vivos. A noção de humanidade (humanitas), elemento de caráter universal - encontrada no direito romano e na obra de pensadores como Cícero, Sêneca, Marco Aurélio e Cipião, o Jovem - deriva da influência da filosofia estóica ${ }^{2}$ em Roma. $^{3}$

Com a redescoberta do pensamento clássico da Idade Média, o jusnaturalismo passa por uma transformação. Tomás de Aquino, no século XIII, lapida a concepção de direito natural até então predominante.

\footnotetext{
${ }^{1}$ Professor e pesquisador na PUC Goiás e na Universidade Salgado de Oliveira. Doutor em Ciências Políticas e Sociais (Université de Liêge, Bélgica).E-mail: phfnunes@gmail.com

2 O estoicismo, doutrina de caráter eminentemente ético, surge com Zenão, cipriota fenício nascido no séc. IV a.C. As "preocupações de Zenão parecem ter sido fundamentalmente de caráter ético. Uma das principais questões que permaneceu de interesse central em toda a filosofia estóica é o grande problema do determinismo e do livre-arbítrio, questão filosófica que tem se mantido suficientemente viva para atrair a atenção dos filósofos através dos séculos até os dias de hoje. Segundo Zenão, a natureza é estritamente regida por leis. Sua teoria cosmológica parece ter sido inspirada, no essencial, nas idéias pré-socráticas. [...] O maior bem é a virtude, que consiste em viver em uníssono com o mundo. No entanto, não se deve interpretar isto como mera tautologia, baseado em que tudo o que é está em completa unissonância com o mundo. Trata-se antes de que a vontade de uma pessoa seja dirigida de tal forma que se misture com a natureza, em vez de se opor a ela. Os bens materiais têm pouco valor. Um tirano pode privar um homem de todas as coisas externas que ele possui, até mesmo da vida, mas não lhe pode tirar a virtude, que é uma posse interna e inalienável. E assim chegamos à conclusão de que, ao rejeitar os falsos atrativos dos bens externos, um homem se torna perfeitamente livre, pois a sua virtude, a única que importa, não pode ser atingida por pressões exteriores" (RUSSEL, 2002, p. 15354).
}

${ }^{3}$ Sobre a influência do estoicismo na filosofia antiga e medieval, cf. Bloch (1980); Cassirer (2003). vol.10, nº. 01, Rio de Janeiro, 2017.pp. 63-81 
Para ele, o Ius Naturale foi criado e atribuído por Deus e, por conseguinte, é imutável e irrevogável. À simplicidade da definição encontrada no texto da Instituta, acrescenta-se a razão. A partir de Tomás de Aquino a razão se torna um elemento indissociável do direito natural. No Tratado sobre a lei, da Suma Teológica (questões 90 a 108), o autor aponta as principais características da lei natural - "participação da lei eterna na criatura racional" (2002, p. 54): instituída e/ou promulgada por Deus; imutável, embora possa sofrer adições decorrentes da razão em benefício da vida humana; superior ao direito positivo (Bobbio, 1995; Erim, 1939), fruto exclusivo da vontade humana (Moura, 1996).

A concepção de razão em Tomás de Aquino consolida a doutrina escolástica, que teve dentre seus precursores nomes como Anselmo de Cantuária, Abelardo e Alberto, o Grande. Seu pensamento finca o marco da filosofia cristã na doutrina jusnaturalista que se estenderá até o séc. XVII. Verifica-se essa harmonia entre cristianismo e jusnaturalismo na relação estabelecida entre a vontade divina e a razão, pois, conforme atesta Cassirer, desde que "a razão e a revelação são expressões diferentes de uma mesma verdade, a verdade de Deus, não é possível qualquer desacordo entre elas" (2003, p. 140).

Hugo Grotius, um dos precursores do jusnaturalismo moderno, define o direito natural no Cap. I do Livro I de seu De Jure Beli ac Pacis (1625):

Natural right is the dictate of right reason, shewing the moral turpitude, or moral necessity, of any act from its agreement or disagreement with a rational nature, and consequently that such an act is either forbidden or commanded by God, the author of nature. The actions, upon which such a dictate is given, are either binding or unlawful in themselves, and therefore necessarily understood to be commanded or forbidden by God. This mark distinguishes natural right, not only from human law, but from the law, which God himself has been pleased to reveal, called, by some, the voluntary divine right, which does not command or forbid things in themselves either binding or unlawful, but makes them unlawful by its prohibition, and binding by its command. [ ... ]

We must farther remark, that natural right relates not only to those things that exist independent of the human will, but to many things, which necessarily follow the exercise of the will (1901, p. 21).

Embora, cronologicamente, Grotius seja um autor moderno, verifica-se que sua obra retrata a transição do jusnaturalismo medieval para o moderno. Conforme ressalta Benítez (1999), o direito natural da Idade Média é de cunho teológico enquanto o da Idade Moderna é essencialmente secular.

As bases do jusnaturalismo moderno já são encontradas em Francisco Vázquez de Menchaca Controversias ilustres y otras de más frecuente uso (1559). No entanto, Grotius parece ter seguido caminho semelhante ao de Francisco de Vitória e Francisco Suárez, os quais expuseram suas ideias ainda de acordo com a filosofia de Tomás de Aquino.

Thomas Hobbes, no cap. XIV do Leviatã (1651), expõe uma visão desvinculada da criação divina, evidência do jusnaturalismo secular:

O Direito de natureza, a que os autores geralmente chamam jus naturale, é a liberdade que cada homem possui de usar o seu próprio poder, da maneira que quiser, para a preservação vol.10, no. 01, Rio de Janeiro, 2017.pp. 63-81 
de sua própria vida; e consequentemente de fazer tudo aquilo que seu próprio julgamento e razão lhe indiquem como meios adequados a esse fim (2000, p. 113).

Além da diferença no tocante à origem da lei natural nas concepções medieval e moderna, ressalta-se que na Idade Média havia uma clara ideia da superioridade dos preceitos jusnaturalistas em relação aos governantes e ao direito positivo. Nesse período, o direito natural desempenha um importante papel de controle da atuação dos governantes, uma vez que nos idos medievos a concepção de governo apresentava traços acentuadamente pessoais (Weckmann, 1993). A consequência dessa pessoalidade exagerada era a confusão entre o domínio público e privado, isto é, uma visão patrimonialista do Estado. O direito natural ocupava função semelhante às das hodiernas garantias constitucionais, visto que representava um limite ao exercício do poder.

John Locke (Bobbio, 1997), no Segundo Tratado sobre o Governo Civil (1690), afirma que existe uma lei da natureza, que visa assegurar a condição natural de perfeita liberdade dos indivíduos:

[...] o estado de natureza tem para governá-lo uma lei da natureza, que a todos obriga; e a razão, em que essa lei consiste, ensina a todos aqueles que a consultem que, sendo todos iguais e independentes, ninguém deveria prejudicar a outrem em sua vida, saúde, liberdade ou posses. Pois sendo todos os homens artefato de um mesmo Criador onipotente e infinitamente sábio, todos eles servidores de um Senhor soberano e único, enviados ao mundo por Sua ordem e para cumprir Seus desígnios, são propriedades de Seu artífice, feitos para durar enquanto Ele aprouver, e não a outrem. E tendo todos as mesmas faculdades, compartilhando todos uma mesma comunidade de natureza, não se pode presumir subordinação alguma entre nós que nos possa autorizar a destruir-nos uns aos outros, como se fôssemos feitos para o uso uns dos outros, assim como as classes inferiores de criaturas são para o nosso uso. Cada um está obrigado a preservar-se, e não abandonar sua posição por vontade própria; logo, pela mesma razão, quando sua própria preservação não estiver em jogo, cada um deve, tanto quanto puder, preservar o resto da humanidade, e não pode, a não ser que seja para fazer justiça a um infrator, tirar ou prejudicar a vida ou o que favorece a preservação da vida, liberdade, saúde, integridade ou bens de outrem (1998, p. 384-385).

Para que este estudo não se limite apenas a clássicos da filosofia e da ciência política europeia, apresentase o conceito de direito natural de Miguel Reale:

O Direito Natural pode ser concebido, in abstracto, como um conjunto de princípios éticos e racionais que inspiram e norteiam a evolução e as transformações do Direito, e que, sem serem redutíveis às categorias do Direito Positivo, banham as matrizes da positividade jurídica. Tal modo de entender o Direito Natural deve pressupor, porém, a sua compreensão como algo de transcendental (no sentido kantiano deste termo), e não de transcendente, em relação ao Direito Positivo: é, em suma, o conjunto das condições lógicas e axiológicas imanentes à experiência histórica do Direito, ou, por outras palavras, corresponde às "constantes" estimativas de cuja validade universal o homem se apercebe na história e pela história (2000, p. 97).

Um dos maiores problemas do jusnaturalismo moderno, intensificado com as doutrinas dos séculos XVII e XVIII - excessivamente abstratas na opinião de Giorgio Del Vecchio (1957) -, diz respeito à validez. A ideia de um direito desprovido de coerção, isto é, "un valor puramente ético y deontológico, independiente de que se confirme efectivamente" (Del Vecchio, 1957, p. 522-523), é largamente rechaçada pela escola positivista clássica ou tradicional nos séculos XIX e XX.

O princípio segundo o qual o soberano não está sujeito a nenhuma autoridade - um marco da doutrina vol.10, n. 01, Rio de Janeiro, 2017.pp. 63-81 
política da baixa Idade Média e da Idade Moderna - é o alicerce da teoria da soberania estatal, que tem entre seus expoentes Georg Jellinek (2000) e Hans Kelsen (1998). Todavia, a superioridade desse valor ético que é o direito natural se faz presente, em maior ou menor grau, em autores como Tomás de Aquino (2002) e Jean Bodin (2000).

Atualmente, o direito natural serve de parâmetro para as declarações de direitos humanos e para a criação de novos direitos e garantias fundamentais. Neste sentido, percebe-se que a afirmação do constitucionalismo moderno, notadamente a partir do final do século XVIII, seguida pelos grandes códigos europeus - nortes do sistema jurídico contemporâneo -, inicialmente foi um obstáculo ao direito natural; entretanto, hodiernamente, o direito natural, expresso em princípios, representa uma utopia pedagógica - necessária -, um valor ético e moral que expressa o mais puro ideal de um dever ser, seja no âmbito do direito interno ou do internacional.

\section{GUILHERME DE OCKHAM E O JUSNATURALISMO}

\section{Guilherme de Ockham: Vida e Obra}

Guilherme de Ockham ${ }^{4}$ viveu em um período conturbado, quando a Europa sofria intensas mudanças políticas, sociais, econômicas e religiosas (Heers, 1981). Com frequência, reserva-se a seu nome um lugar secundário na filosofia política; alguns intelectuais, a exemplo de Gaetano Mosca, vinculam suas ideias ao pensamento de Dante Alighieri e/ou Marsílio de Pádua, como se fosse um autor de somenos importância.

Um outro escritor político desta época é o inglês Guilherme de Ockam, apelidado doctor invincibilis et subtilissimus, que, tomando partido ao lado do Imperador Luís da Baviera, sustenta a independência do poder imperial em relação à Igreja. Mas, se o pensamento deste escritor aproxima-se algumas vezes das idéias modernas, a forma que emprega é estritamente escolástica, isto é, desagradável à nossa mentalidade (Mosca, 1987, p. 92).

$\mathrm{Na}$ teologia ou na filosofia escolástica, Duns Scotus, costuma ser a preferência entre os estudiosos. Outros, a exemplo de Luís Weckmann, outorgam a Ockham, juntamente com Marsílio de Pádua, o título de "luminarias políticas de un mundo por venir" (1993, p. 169).

Guilherme de Ockham é um dos vultos da escolástica tardia ou baixa escolástica. Suas ideias, muitas vezes objeto de interpretações conflituosas, são precursoras da doutrina nominalista, ingrediente importante da passagem do universalismo de Tomás de Aquino para o individualismo dos idos futuros. Goyard-Fabre (1999, p. 79), com base em Von Gierke, registra que:

[...] a passagem da universitas para a societas constituiu, na história jurídico-política medieval, uma guinada capital. No nominalismo de Guilherme de Occam, que é sua transposição filosófica, a comunidade humana já não era pensada como um todo no qual os homens eram apenas partes indissociáveis; ela resultava, antes, de uma associação ou da soma de indivíduos e em cada societas assim formada as vontades individuais constituíam o ponto de

${ }^{4}$ Dentre as muitas grafias para designar o autor, encontram-se Occam, Ockham, Ockam, Olram, Hokan. vol.10, no. 01, Rio de Janeiro, 2017.pp. 63-81 
partida e o princípio da ordem política que elas constroem.

A obscuridade que envolve Guilherme de Ockham não se limita às suas ideias. O mesmo ocorre em relação à sua biografia: os registros concernentes ao ano de seu nascimento, em Ockham - localidade próxima à Londres no condado de Surrey -, são bastante díspares: "1270" (ERIM, 1939, p. 96); "entre 1280 e 1300" (RUSSEL, 2202, p. 226); “pouco antes de 1300 (GILSON, 1995, p. 795) "; "por volta de 1280” (GHISALBERTI, 1997, p. 15); "entre 1285 e 1290" (KRITSCH, 2002, p. 511); "entre os anos de 1280 e 1290" (VIER, 1997a). Sua morte ocorreu, entre 1349 e 1350, em Munique.

Ainda jovem, ingressou na Ordem Franciscana. Frade, teólogo, filósofo, Ockham estudou na Universidade de Oxford, onde obteve o título de inceptor - bacharel formado (baccalaureus formatos) - em 1318. Daí vem a expressão mais utilizada para designá-lo na literatura: Venerabilis Inceptor. Todavia, segundo Ghisalberti (1997), deduz-se a partir de alguns documentos que Ockham chegou a ser mestre e não apenas um bacharel. Em um ato de abril de 1328, João XXII conferiu ao então inceptor o título magister in sacra pagina a pedido de Miguel de Cesena.

Os desentendimentos e problemas de Ockham com a Igreja começaram ainda em Oxford por defender ideias e doutrinas pouco ortodoxas, que repercutiram amplamente no círculo acadêmico. De acordo com Vier (1997a, p. 142),

[...] as preleções sentenciárias ${ }^{5}$ de Ockham produziram um impacto profundo na universidade. Estudantes e mestres logo se deram conta de que surgira uma nova estrela no céu da teologia e da filosofia, um luminar que ousava enfrentar, com seu espírito crítico penetrante, não somente as autoridades de menor porte, mas até mesmo ao seu grande predecessor, o venerado João Duns Escoto; tanto assim que, entre os títulos magisteriais de Ockham, figura o de Doctor plusquam subtilis, Doutor mais que sutil.

Apesar do sucesso dos escritos de Ockham, um grupo de oposição às suas ideias foi constituído, liderado por ninguém menos John Lutterel, chanceler da universidade e defensor das teses tomistas. Lutterel foi destituído de seu cargo pelo Bispo de Lincoln, Henrique Burwasch, decisão apoiada por professores partidários de Ockham.

O ex-chanceler, autorizado pelo rei Eduardo II, foi à Avinhão ${ }^{6}$, com o pretexto de apelar ao papa da decisão que havia lhe removido do cargo. Não obstante, ele denunciou a João XXII que ex-aluno desenvolvia e disseminava ideias contrárias à doutrina católica.

Em decorrência da acusação, Ockham foi chamado a Avinhão, em 1324, momento em que se vê forçado a interromper seus estudos em Oxford. Constituiu-se uma comissão pouco imparcial, da qual o próprio Lutterel

\footnotetext{
${ }^{5}$ As "preleções sentenciárias" também são conhecidas como Comentários às Sentenças.

${ }^{6}$ A sede do papado foi transferida para a cidade francesa de Avignon no ano de 1309. Era papa naquele momento Clemente V eleito em 1305. Antes da eleição de Clemente V houve um longo período de vacância no papado, pois seu antecessor Bonifácio VIII havia falecido em 1303 após a humilhante derrota na querela com o rei francês Felipe IV (Cf. RUSSEL, 2002).
} 
fez parte, para apreciar os trabalhos de Ockham. ${ }^{7}$ Entre três e quatro anos depois, a comissão chegou à seguinte conclusão sobre os 51 artigos examinados: sete eram heréticos; a maioria continha ideias de menor potencial ofensivo (falsas; ridículas ou temerárias); e apenas três não sofreram nenhum tipo de censura.

A condenação de Ockham não chegou a ser homologada pelo papa em virtude de uma outra disputa que se desenrolava simultaneamente, de maior proporção e relevância: a questão da pobreza apostólica.

Os espirituais, um setor extremo da Ordem Franciscana, que levava muito a sério o voto de pobreza, haviam sido o alvo do descontentamento papal. Durante algum tempo vigorara um compromisso segundo o qual o papa conservara a propriedade formal dos bens da Ordem. Isto fora revogado e muitos desafiaram a autoridade papal (RUSSEL, 2002, p. 226).

Ockham entra na questão da pobreza apostólica num momento em que a interpretação da renúncia total à propriedade por parte de Cristo e dos apóstolos era abertamente condenada pela cúria papal. João XXII defendia posição inversa à dos franciscanos e, em 1323, reputou a tese da renúncia total herética. ${ }^{8}$

Miguel de Cesena, Ministro Geral da Ordem Franciscana, foi chamado a Avinhão pelo papa no final de 1327. Nesse momento, abrem-se as portas da filosofia política para Guilherme de Ockham, agora envolvido não apenas numa contenda entre facções eclesiásticas, mas na linha de fogo da luta entre os poderes régio e papal.

O geral da ordem, Miguel de Cesena, chegado a Avinhão em 10 de dezembro de 1327, em obediência a um convite explícito do papa, e pressentindo a tempestade que estava prestes a abater-se sobre a ordem, procurou cercar-se de homens dispostos a abraçar sua causa e a sustentar as razões favoráveis não só à sua concepção a respeito da pobreza evangélica, mas também à causa de Luís da Baviera, que se proclamara imperador e agia como tal, embora não tivesse obtido a investidura do papa. Ockham, decepcionado pelo espetáculo oferecido pela corte pontifícia e influenciado pelo procurador da ordem, Bonagrazia de Bergamo, colocou-se logo à disposição de seu geral e por solicitação deste examinou as constituições pontifícias Ad conditorem canonum ( 8 de dezembro de 1322) Cum inter nonnulos (12 de novembro de 1323), Quia quorundam mentes (10 de dezembro de 1324), nas quais o pontífice contestava, ponto por ponto, as idéias de Miguel de Cesena e da parte da ordem que o seguia, a respeito da pobreza (GHIISALBERTI, 1997, p. 20).

O parecer de Ockham sobre os documentos analisados a pedido de Miguel de Cesena foi contumaz.

Assim como a comissão encabeçada por Lutterel considerou suas ideias heréticas, ele o fez em relação às constituições pontifícias. ${ }^{9}$

Em 1328 - final de maio ou começo de junho, provavelmente - acontece o cisma menorita, isto é, a fuga do Ministro Geral da ordem acompanhado de outros frades menores. O grupo ganhou a proteção do Imperador Luís da Baviera, inicialmente em Pisa e, em seguida, na sua corte em Munique. Nesse período Ockham escreveu seus principais textos políticos: Opus nonaginta dierum (1333/1334); Dialogus (1333/1341); Epistola ad frates

\footnotetext{
${ }^{7}$ Além de John Lutterel, fizeram parte da comissão: "Raimundo Bequini, dominicano, patriarca de Jerusalém; Durando de São Porciano, dominicano, bispo de Meaux; Domingos Grima, dominicano, bispo eleito de Pamiers; Gregório, agostiniano, bispo de Belluno-Feltre; João Paynhota, agostiniano, mestre de teologia” (GHISALBERTI, 1997, p. 18).

${ }^{8}$ Ockham também esteve envolvido na disputa entre os Wittelsbach e os Luxemburgo, que lutavam pela titularidade do mais alto posto secular do Sacro Império Romano-Germânico.

${ }^{9}$ Um bom exemplo dos ataques inflamados de Ockham contra as constituições pontifícias é o cap. XXVII de seu tratado político Sobre o poder dos imperadores e dos papas (De Imperatorum et Pontificum potestate), de 1347.
} 
minores in capitulo apud Assisium congregatos (1334); De dogmatibus papae Johannis XXII(1334); Tractatus contra Johannem XXII (1335); Tractatus contra Benedictum XII(1337/1338); Compendium errorum papae Johannis XXII (1338); Allegationes de potestate papae (1338); An princeps (1337/1340?); Breviloquium de potestate Papae (1341/1342); Octo quaestiones (1342); Tractatus de jurisdictione imperatoris in causis matrimonialibus (1341/1342); De Imperatorum et Pontificum Potestate (1347) ${ }^{10}$.

O Venerabilis Inceptor, assim como os demais menoritas refugiados na corte do Imperador, foi vítima da excomunhão no mesmo ano do cisma e definitivamente expulso da Ordem Franciscana em 1331.

\section{O pensamento de Guilherme de Ockham ${ }^{11}$}

Analisa-se nesta seção, em linhas gerais, o pensamento do Venerabilis Inceptor, um franciscano rebelde e de pena afiada.

No prólogo da Exposição dos Oito Livros da Física, lê-se um trecho que revela alguns traços da personalidade de Guilherme de Ockham enquanto homem das idéias (1979, p. 347):

[...] da mesma maneira como às vezes reprovarei com toda modéstia e sem malícia as opiniōes dos outros, estou pronto pacientemente a ser repreendido se disser alguma coisa que não concorda com a verdade. Aquele que corrige, porém, tome cuidado para que, apoiado em maus princípios adquiridos, não se transforme, por favor ou por ódio, de corretor em pervertedor. Observe, além disso, que não posso adaptar-me a opiniões que se contradizem.

Dentre as palavras dedicadas a seus desafetos e às suas respectivas idéias e ações, dentre eles os papas João XXII (1316-1334) e Benedito XII (1334-1342), encontram-se amiúde expressões como: estulto; absurdo; herético; "Benedito, apenas no nome, não nas atitudes"; ímpio; cruel; ridículo; fantasioso; indigno; tirano; injusto; insano; anticristão.

Um elemento de grande relevância nos escritos de Ockham é a forma como tratou o conhecimento, "qualidade existente na alma humana como sujeito, ou uma coleção de alguma dessas qualidades que informam a alma" (1979, p. 347-348). Para ele, o conhecimento pode ser dividido em duas categorias fundamentais: o intuitivo e o abstrativo, definidos na Ordinatio (Ordenação), ou Scriptum in librum primum Sententiarum (Comentário ao Primeiro Livro das Sentenças):

[...] o conhecimento intuitivo é tal, que, quando umas coisas são conhecidas, se alguma coisa

\footnotetext{
${ }^{10}$ As seguintes obras políticas de Guilherme de Ockham foram publicadas no Brasil: a) Brevilóquio sobre o principado tirânico (trad. de Luís de Boni, editora Vozes); b) Oito questóes sobre o poder do papa (publicadas em parceria pela EDIPUCRS e pela USF, com tradução, introdução e notas de José Antônio de C. R. de Souza; c) Tratado contra Benedito (Livro VI), Pode um príncipe (An princeps), Consulta sobre uma questão matrimonial, Sobre o poder dos imperadores e dos papas - essas últimas compõem um volume que leva o título "Guilherme de Ockham: obras políticas", traduzido e publicado pelas mesmas editoras citadas no item "b" desta enumeração.

${ }^{11}$ Não se trata aqui do "Ockhamismo" ou do movimento ockhamista, tarefa que exigiria um estudo mais aprofundado e verticalizado do que o ora apresentado. Para maiores informações sobre o movimento ockhamista, cf. COURTENAY (2008); GILSON (1995).
} 
for inerente a outra, ou distar localmente de outra, ou tiver qualquer relação com ela, logo, em virtude do conhecimento incomplexo daquelas coisas, fica ciente se há inesão de uma coisa na outra, se dista ou não, e assim fica sabendo todas as outras verdades contingentes, a não ser que tal conhecimento seja fraco demais ou que haja qualquer outro impedimento. [...] E, falando em geral, todo conhecimento incomplexo de um termo ou de termos, de uma coisa ou de coisas, em virtude do qual se pode conhecer evidentemente alguma verdade contingente, sobretudo de fatos presentes, é um conhecimento intuitivo.

O conhecimento abstrativo, porém, é aquele em virtude o qual não se pode conhecer com evidência se uma coisa contingente existe ou não. Portanto, o conhecimento abstrativo abstrai da existência e não-existência, porque, ao contrário do que ocorre com o conhecimento intuitivo não se pode conhecer por ele, com evidência, se existe uma coisa existente de fato ou se não existe uma coisa inexistente (OCKHAM, 1979, p. 356).

O conhecimento intuitivo permite chegar à verdade dos fatos. $O$ "incomplexo", ao qual Ockham se refere acima, leva à compreensão dos objetos simples ou de única essência e se opõe ao “complexo”, voltado para várias essências reunidas ou agrupadas. O conhecimento intuitivo pode ser perfeito e imperfeito. Este deriva do contato direto e atual com o objeto; aquele, de um contato direto, mas pretérito, isto é, fruto de informações anteriormente obtidas e armazenadas na mente humana.

O conhecimento abstrativo, por sua vez, não permite chegar à veracidade de um fato ou à compreensão efetiva de um objeto, uma vez que dispensa a presença, atual ou pretérita, ou a constatação da ausência do objeto. E, assim como o conhecimento intuitivo, pode ser dividido em dois: "o primeiro [...], representado pelo conhecimento abstrativo que sempre e imediatamente vem acompanhado do conhecimento intuitivo; o segundo tipo, pelo contrário, é dado pelo conhecimento conceitual verdadeiro e próprio, ou conhecimento do universal” (GHISALBERTI, 1997, p. 68-69).

O universal - concepção oposta à de singular - é, para Guilherme de Ockham, produto do intelecto humano. O tratamento que ele confere aos universais diverge dos demais filósofos da escolástica, os quais consideravam-nos elementos independentes do conhecimento humano. Nas palavras do Venerabilis Inceptor (1979, p. 362),

[...] o universal é uma intenção mental, capaz de ser predicada de muitas coisas. Isso também pode ser confirmado pela razão. Com efeito, toda gente reconhece que todo universal é predicável de muitas coisas; ora, só uma intenção mental ou um sinal voluntariamente instituído é um universal. Aqui, porém, não emprego 'universal' como sinal voluntariamente instituído, mas como aquilo que naturalmente é universal [...]

Do mesmo modo, uma proposição só pode estar na mente ou na palavra falada ou escrita; logo, suas partes só podem estar na mente ou na palavra falada ou escrita; ora, essas coisas não são substâncias particulares. Está certo, portanto, que nenhuma proposição pode ser composta de substâncias, pois é feita de universais, e estes não são de maneira alguma substâncias.

Os universais não possuem existência própria. Contudo, não devem ser tomados como mera abstração pois são concebidos a partir da percepção do singular, ou, consoante Russel, os universais “[...] surgem da semelhança entre as coisas, porém uma semelhança não é uma coisa, como o realismo erroneamente supõe” (RUSSEL, 2002, p. 213). Daí o emprego do termo nominalismo para explicar o pensamento de Ockham: os 
universais só existem nas expressões do intelecto humano, sobretudo na forma de palavras ou nomes.

O coletivo só existe por causa do individual. Então o indivíduo pode e deve ser tomado em sua individualidade antes de inserido em um contexto universal (humanidade, sociedade, Estado). Em contrapartida, os elementos universais só devem ser concebidos após o conhecimento do indivíduo. Em suma, uma sociedade, um Estado ou mesmo toda a comunidade cristã, possui natureza meramente quantitativa, de modo que sua existência não significa - em um primeiro momento - nada além de um agregado de homens.

Ockham também sustenta que o conhecimento experimental (empírico) deriva do intuitivo. A experiência vivenciada distingue as pessoas; quem vivencia uma experiência, conclui, adquire conhecimento inatingível para quem não vivencia tal experiência. O conhecimento meramente abstrato é, portanto, deficiente: 0 "único meio de provar que uma coisa é a causa de outra é, pois, recorrer à experiência e raciocinar pela experiência e a ausência” (GILSON, 1995, p. 798).

Para Ockham, não se obtém a verdade senão pela intuição. Todavia, essa regra não é absoluta pois $O$ conhecimento intuitivo pode referir-se a coisas inexistentes pelo poder divino. Pergunta-se então: o que houve com a experiência relacionada ao conhecimento intuitivo? A resposta: o conhecimento experimental começa no intuitivo, mas não consegue explicar tudo. A filosofia possui limites intransponíveis. Se o homem não é perfeito, sua capacidade intelectiva também não é. A razão não pode fornecer resposta para todas as indagações humanas.

Dessa forma, Ockham assegura um terreno próprio para a filosofia e outro para a teologia. Ao reconhecer os limites da filosofia e da razão, ele abre espaço para uma teologia racional cujo escopo, segundo Ghisalberti, é "fazer uma admoestação à razão, a fim de que não ultrapasse seus limites no discurso teológico" (1997, p. 157).

Dentre as coisas que não podem ser provadas senão pela Verdade revelada, encontra-se Deus. Sua existência não pode ser demonstrada por meios filosóficos ou racionais. Ademais, nem todo indivíduo crê na existência de Deus. Por conseguinte, essa matéria deve ser reservada unicamente à fé.

Dessarte, filosofia e teologia possuem objetos e métodos próprios, não coincidentes. E a teologia, ao contrário da filosofia, não é uma ciência capaz de demonstrar suas proposições e conclusões. Ockham, desse modo, prefere afastar as indagações de cunho teológico e reservar à filosofia as questões que podem ser demonstradas pela razão ou, nas palavras de Etienne Gilson, ele “[...] se dedicará ativamente a explicar as coisas da maneira mais simples possível e a varrer o campo da filosofia das essências e das causas imaginárias que a entulham" (1995, p. 798).

O Venerabilis Inceptor, tanto em seus escritos puramente filosóficos quanto nos políticos, dedica especial atenção à liberdade, elemento indissociável da vontade. Esta - e, por conseguinte, a liberdade - pressupõe uma natureza racional; trata-se da "[...] primeira coisa que se encontra em poder do homem [...], e nada se encontra em poder dele a não ser mediante a vontade" (GHISALBERTI, 1997, P. 239).

No entanto, a vontade humana não conduz necessariamente a Deus. Ainda que a ela leve a um ideal de vol.10, no. 01, Rio de Janeiro, 2017.pp. 63-81 
felicidade, o indivíduo pode renunciar à felicidade simplesmente por não acreditar que seja algo atingível.

Enquanto livre, a vontade permanece indeterminada e, portanto, capaz de autodeterminar-se ante qualquer objeto. Seja qual for a força persuasiva das razões do intelecto, ele não está apto a determinar à vontade, nem mesmo quando se trata do sumo bem, colhido em toda sua clareza (GHISALBERTI, 1997, p. 242).

A noção de livre-arbítrio do pensador medieval é bastante avançada para sua época. Primeiro, por não colocar Deus como objeto último da vontade humana, posição nada convencional para um clérigo no séc. XIV; em segundo lugar, por admitir que a vontade humana é livre ao ponto de renunciar à própria felicidade.

As ideias do Venerabilis Inceptor e alguns de seus contemporâneos, mormente Marsílio de Pádua, foram muito ousadas mesmo para os reformadores. Duncan B. Forrester (1993, p. 308) lembra que

Lutero se muestra sustancialmente de acuerdo (en la relación de la razón y de la revelación) con Occam y con los nominalistas, pero acaba por rechazarlos también a ellos como pelagianos que "no sólo han ensombrecido el Evangelio, sino que se lo han llevado, y han enterrado a Cristo por completo", como resultado de una visión no bíblica de las potencialidades del hombre.

Além dos elementos expostos anteriormente (vontade, liberdade e razão), o individualismo de Ockham reserva lugar de destaque para a propriedade. O poder que o indivíduo exerce sobre os bens tem a mesma natureza daquele exercido sobre as pessoas. Desse modo, "o direito de propriedade e o direito de ser constituído como autoridade, a posse dos bens materiais e a habilidade de exercer qualquer poder, são dois aspectos indistinguíveis de um único poder" (GHISALBERTI, 1997, p. 280).

A origem do direito de propriedade é um ponto interessante da obra de Guilherme de Ockham. Ele atribui à razão humana a origem do direito de propriedade: no início, Deus concedeu aos homens o direito ao uso comum de todas as coisas, mas concedeu-lhes também a razão para determinar a melhor forma de se disporem dos bens que porventura possuíssem. Assim, a propriedade coletiva tem natureza divina, mas a propriedade privada é oriunda da vontade humana.

Ockham, assim como Tomás de Aquino, refuta o argumento segundo o qual a propriedade coletiva (uso comum), instituída pela vontade divina, era obrigatória e a privada somente surgiu com o pecado original. Entretanto, a interpretação de Ockham não coincide com a do Aquinate. Este considera a propriedade um direito natural por ter origem divina direta; aquele vê na propriedade uma natureza essencialmente humana. Para o Venerabilis Inceptor, a propriedade privada somente pode ser concebida como um direito natural indiretamente: Deus outorga aos homens a razão e da razão humana deriva a propriedade privada (GHISALBERTI, 1997; MCGRADE, 1974).

Cumpre ressaltar que as ideias de Guilherme de Ockham tem reflexo direto na teoria da soberania 
popular ${ }^{12}$. Lê-se no cap. IV de An princeps (Pode um príncipe):

[...] as autoridades seculares, a saber, a imperial, a régia e outras relevantes, são estabelecidas por Deus, não mediante a autoridade pontificia, mas através da autoridade dos homens, a qual receberam, não do papa, mas de Deus. Por isso, o poder real não provém do pontífice, mas de Deus, por intermédio do povo, que dele recebeu o poder para estabelecer para si um rei que os governe com vista à obtenção do bem comum (OCKHAM, 1999b, p. 98-99).

Finalmente, registra-se que Guilherme de Ockham se opôs veementemente às doutrinas hierocráticas (NUNES, 2005), defensoras da supremacia do poder papal frente ao poder secular. Esse assunto será abordado com maior profundidade na seção subsequente.

\section{Elementos do Jusnaturalismo em Sobre O Poder Dos Imperadores E Dos Papas}

Dedica-se esta seção a uma análise mais pormenorizada do último tratado político escrito por Guilherme de Ockham: Sobre o poder dos imperadores e dos papas (De Imperatorum et Pontificum Potestate). Certamente, essa não é sua obra política mais densa... tal título caberia melhor para o Brevilóquio sobre o principado tirânico (1988) ou para as Oito questóes sobre o poder do papa (2002). Não obstante, o texto escolhido reúne argumentos explorados em outros trabalhos e é mais adequado para um artigo. Pode-se dividir Sobre o poder dos imperadores e dos papas em três partes: a) cap. I a XIV: análise dos limites impostos ao exercício do poder papal, quando da instituição do principado apostólico, e de como os sumos pontífices vinham desrespeitando esses limites; b) cap. XV a XXVI: exame do comportamento errôneo dos papas em desrespeito aos governantes seculares; c) cap. XXVII e XXVIII: comentários às heresias - $\operatorname{erros}^{13}$ - cometidos pelo papa João XXII (1316-1334) e seus sucessores - Benedito XII (1334-1342) e Clemente VI (1342-1352).

De Imperatorum et Pontificum Potestate foi escrito por ocasião da eleição de Carlos de Luxemburgo como anti-rei da Alemanha e anti-imperador em 11 de julho de 1346, fruto da artimanha tramada por João da Boêmia, seus filhos Carlos - eleito imperador - e João Henrique, e seu irmão, o arcebispo Balduíno. Consolidada a aliança, o papa

[...] Clemente VI, primeiramente enviou a Ludovico IV um documento em que exigia dele uma submissão em termos bastante afrontosos à dignidade imperial, cuja resposta o papa de antemão já sabia qual era. Em seguida, substituiu o arcebispo de Colônia, Henrique de Virneburg, há muito tempo fiel aliado de Ludovico IV, pelo jovem conde Gerlach de Nassau, medida essa que acabou por intimidar o arcebispo de Mogúncia, que ficou com receio de vir a perder o seu arcebispado pela mesma razão, embora na prática ela não tivesse causado o efeito desejado, porque Henrique continuou a governar a arquidiocese com o apoio do cabido. Depois, em setembro de 1344, conclamou os príncipes eleitores, um a um, a eleger um novo rei da Alemanha, a ser, mais tarde, promovido a imperador, dado que o império

\footnotetext{
${ }^{12}$ Nesse aspecto Wyclif, Ockham, Marsílio de Pádua são igualmente à frente de seu tempo. Segundo Forrester, "[...] los reformadores convienen con los teóricos antipapistas medievales como Wiclef, y con Marsilio y Occam, salvo cuando estos pensadores hablaron de la soberanía popular" (1993, p. 313).

Sobre esse tema, sugere-se a leitura de SKINNER $(2002 ; 1996)$.

${ }^{13}$ No cap. XXVII, Ockham apresenta vinte e oito erros, ou heresias, cometidos pela Igreja de Avinhão.
} vol.10, nº. 01, Rio de Janeiro, 2017. pp. 63-81 
estava sendo governado por um excomungado. Enfim, em 13 de abril de 1346, Clemente VI, após ter renovado a excomunhão contra o imperador, ordenou que todos os príncipes cristãos, recorrendo à força, o expulsassem de seus domínios, como se fosse uma guerra santa, e que os eleitores procedessem a uma nova eleição imperial, a qual ocorreu em 11 de julho do mesmo ano[...] (SOUZA, 1999, p. 166).

Ockham defende a separação das funções e dos poderes secular e eclesiástico. Dessarte, não há que se falar em supremacia de um sobre o outro. O principado papal é o mais sublime dos principados pelos seguintes motivos: diz respeito às coisas espirituais, “[... as quais são mais dignas do que as seculares [...]”; “[...] pelo fato de ser um principado que concerne a pessoas livres, não a escravos [...]"; e, por último, porque "o papa, graças ao direito divino, pode regular ou ocasionalmente fazer tudo o que é necessário para o regime e o governo dos fiéis, embora tenham sido ordinária ou regularmente estabelecidos certos limites para o exercício de seu poder, os quais normalmente não lhe seja lícito ultrapassar" (OCKHAM, 1999d, p. 198-199).

Apesar da sublimidade do principado papal, ou apostólico, a autoridade eclesiástica não deve se intrometer nos assuntos seculares. Uma vez que o poder eclesiástico é exercido sobre pessoas livres, o principado apostólico é enquadrado na modalidade real, categoria oposta a tirânico ou despótico. Ademais, o principado apostólico é ministrativo, isto é, “[...] foi instituído por causa da utilidade e do proveito dos seus súditos, não por causa da honra ou da glória ou da utilidade ou do proveito temporal do governante [...]" (OCKHAM, 1999d, p. 183).

O exercício das funções eclesiásticas, segundo Ockham (1999d, p. 194), deve ser restrito às atividades indispensáveis ao governo dos fiéis, a saber:

[... é da competência do papa, e de todos os bispos em geral, fazer tudo aquilo que é próprio e indispensável aos cristãos, no tocante à "leitura da Escritura", à pregação da palavra de Deus", à organização do culto divino, e tudo aquilo que é necessário e próprio dos cristãos, a fim de que possam vir a alcançar a salvação eterna; e tais coisas não há entre os infiéis. [...]

Em caso, porém, de necessidade ou de utilidade, que pode ser equivalente a necessidade, poderá, então, e deverá se envolver com os negócios temporais, quando faltarem todos os outros a quem competia cuidar disso, suprindo a condenável e perigosa negligência deles.

Para Ockham, a plenitudo potestatis do papa só pode extrapolar suas funções regulares diante de excepcional necessidade ou utilidade. Assim, a atuação do poder eclesiástico em assuntos temporais é subsidiária e temporária, quando a inércia puder ser mais danosa do que sua intromissão.

[...] o principado papal absolutamente não se estende, de maneira regular, sobre os direitos e as liberdades de outras pessoas, a saber, dos imperadores, dos reis, dos príncipes e de outros leigos, ao ponto de o papa poder aboli-los ou prejudicá-los, porque tais direitos e liberdades quase sempre fazem parte das coisas seculares, às quais, conforme antes foi demonstrado, $\mathrm{o}$ poder papal de modo algum se estende regularmente (1999d, p. 178-179).

Regularmente, contudo, o papa não deve se intrometer nos negócios temporais, nos quais estão incluídos os direitos e liberdades dos indivíduos, e até mesmo os direitos e liberdades dos infiéis. 
Segundo o Venerabilis Inceptor, é indispensável delimitar o poder papal, pois só assim se pode garantir eficazmente que o sumo pontífice não exceda sua competência. E tal delimitação deve ser aprovada pelos leigos e pelos clérigos, posto que "[... nunca se estabelecerá paz verdadeira entre os ocupantes da Sé Apostólica e os outros cristãos, a não ser que se determine irrefragavelmente qual é o poder que o papa possui, graças ao direito divino, e que isso venha a ser sancionado pelos clérigos e pelos leigos" (1999d, p. 219). A delimitação da potestade é um elemento primordial, sobretudo em função da sua origem: o poder é de origem divina mas requer o intermédio do povo, sua verdadeira fonte. ${ }^{14}$

Quanto ao jusnaturalismo, destacam-se três elementos: liberdade, propriedade, igualdade. A lei natural, seja de origem divina ou humana, possui um valor hierárquico superior ao poder dos governantes seculares ${ }^{15}$ : “[...] nenhum senhor temporal, de direito, possui tamanho poder sobre seu servo, considerando este termo em sua acepção mais estrita ${ }^{16}$ ao ponto de lhe poder impor tudo aquilo que não contraria, nem a lei divina, nem a lei natural" (OCKHAM, 1999d, p. 174) ${ }^{17}$.

E, da mesma forma que os soberanos temporais, o sumo pontífice também encontra limites na lei natural:

[...] a sentença, inclusive a proferida pelo verdadeiro vigário de Cristo, não deve ser acatada, se for contrária ao direito divino e ao direito natural, porque ambos são mais nobres, dignos e indispensáveis - e não podem ser menos desobrigados de seu cumprimento - do que as leis e os cânones, de maneira que o vigário de Cristo pode muito menos contra eles do que os prelados inferiores contra os cânones (OCKHAM, 1999d, p. 200). ${ }^{18}$

Em vários capítulos da obra em comento, encontram-se passagens que condenam a intromissão do poder papal nos direitos e liberdades individuais; eis um bom exemplo: "[...] o papa não pode subtrair de ninguém o seu direito, especialmente pelo fato de não o ter recebido dele próprio, mas de Deus, ou da natureza ou de outrem. E, pela mesma razão, não pode privar outras pessoas de gozarem das suas liberdades, as quais foram-lhes concedidas ou por Deus ou pela natureza" (1999d, p. 179). O argumento de Ockham, quanto à origem dos

\footnotetext{
14 "Nearly two centuries before Luther and Melanchthon made their appeal to the maxim vim vi repellere licere, we already find William of Ockham arguing in the same fashion in his Octo Quaestiones de Potestate Papae. Discussing the jural relationship between the pope and the emperor in his second Quaestio, Ockham considers the parallel question of the relationship between a kingdom and its king. He concedes that 'the king is superior to his whole kingdom in the ordinary course of events'. But he instantly qualifies this doctrine with the claim that in certain circumstances he is inferior to the kingdom'. This is said to be proved by the fact that 'in cases of necessity it is lawful for the subjects of a kingdom to depose their king and keep him in custody'. And this in turn is said to be justified by the fact that 'we have it from the law of nature that anyone may lawfully repel force with force" (SKINNER, 2002, p. 254).

${ }^{15}$ No tratado político An princeps (OCKHAM, 1999b), os direitos naturais aparecem como elementos que podem fundamentar uma guerra justa.

${ }^{16}$ Para uma maior compreensão do que Ockham enfatiza quando se refere a servo, cf. Weckmann (1993).

${ }^{17}$ Argumento idêntico aparece no cap. II de An princeps: "De fato, qualquer senhor temporal não pode exercer um poder ou domínio mais amplo sobre seu servo, ao ponto de lhe ordenar tudo o que deseja, desde que isto não seja contrário às leis divina e natural. Na verdade, a autoridade que um imperador, rei ou qualquer outro senhor temporal possui sobre todos os seus servos, absolutamente não se estende para além daquelas coisas que são contrárias à lei divina e ao direito natural indispensável" (OCKHAM, 1999b, p. 86).

${ }^{18}$ Argumento semelhante é encontrado no An princeps - cap. XI, in fine, e XII (1999b) e em BODIN (2000).
} 
direitos e liberdades é diametralmente oposto às doutrinas hierocráticas. Para os hierocratas, a autoridade pontifícia é a origem de todos os direitos dos indivíduos, uma vez que o papa é o representante da vontade divina. Ockham nega a ideia de personificação de poder e valoriza a Igreja enquanto instituição. Assim, o sumo pontífice seria a cabeça dessa instituição, mas não a própria Igreja, muito menos a representação da vontade divina.

A liberdade não consiste apenas no direito de ir e vir. O Venerabilis Inceptor faz referência à liberdade intelectual e à liberdade de expressão. No De Imperatorum et Pontificum Potestate, o autor condena a Igreja de Avinhão - sede do principado apostólico - por perseguir aqueles que se atrevem a discutir os limites do poder papal.

A fim de agir mais livremente e sem nenhum receio, ela, não sem lançar mão de um toque de tirania, persegue os que, com reta intenção, não têm medo de disputar acerca de seu poder; de modo que nenhum doutor ou leitor nas universidades e nos outros centros de estudos possa propor e ouvir para debate qualquer questão acerca do poder do papa, e que deva ser definida. No entanto, disputar acerca do poder do papa - não com a intenção de suprimi-lo ou de reduzi-lo ou de colocar em dúvida tudo aquilo que se deve acreditar a seu respeito, mas com o propósito de refutar os que erram acerca de sua dimensão efetiva, ou diminuindo-o ou aumentando-o mais do que convém, e trazendo à luz do dia tudo o que se desconhece sobre o poder papal - deve ser uma coisa bem oportuna e agradável, tanto para o papa quanto para todos os súditos, pois a eles todos convém saber qual e quanto poder ele possui e por força de que direito. [...]

[...] a igreja de Avinhão injuria os escolásticos e outras pessoas, ao atemorizá-los, dizendo que não ousem disputar e publicar a respeito do poder papal, e que encontrarão tudo a seu respeito registrado e documentos autênticos e fundamentados (1999d, p. 201-202).

Benedito XII, sucessor de João XXII, promulgou uma bula na qual vedava a todo clérigo e leigo qualquer pronunciamento sobre questão relativa à fé submetida à Sé Apostólica. A manifestação do papa se tornou vinculante, de modo que os demais membros da Igreja deveriam acatá-la. Sobre o conteúdo dessa bula, assim manifestou Guilherme de Ockham (1999d, p. 251-252):

[...] evidentemente constata-se que o autor da mesma se reputa com o direito de dominar, não apenas sobre as pessoas e os seus bens, mas igualmente sobre a fé dos cristãos, ao ter dito que toda a doutrina em que eles acreditam depende de seu julgamento e confirmação, de modo que se destrói toda a vida cristã, uma vez que nela parece não haver nada de certo e firme. Com efeito, nenhum artigo da fé, acerca do qual não possa surgir uma questão ou dúvida, sobre o qual não possam originar opiniōes diferentes e contrárias, tem de ser apresentado ao exame da Sé Apostólica. Logo, se semelhantemente uma questão ou uma dúvida sobre qualquer artigo da fé for apresentada ao exame daquela mencionada pessoa, a partir daquele instante, nenhum frade menor deve determinar, optar ou concordar com ela, até que a outra parte se manifeste a respeito, o que outra coisa não é senão esvaziar toda a fé católica. Ora, jamais algum herege ousou afirmar explicitamente esse erro, embora a igreja de Avinhão, mediante as suas ações e comportamento demonstre que o professa.

Referente à propriedade, Ockham entende que sua instituição tem origem imediatamente humana:

Deus instituiu o uso comum, mas conferiu ao homem a razão para dividir a res comunis conforme julgasse necessário. A tese segundo a qual Cristo foi o senhor e possuidor de todos os bens materiais e, posteriormente, transferiu esse dominium ao principado papal é rejeitada. Assim como o principado apostólico não se estende regularmente sobre o direitos e liberdades de outrem, também não se estende sobre os bens. 
O principado papal só poderia exigir bens de seus súditos para suprir suas necessidades e realizar devidamente suas funções. De outra forma, não poderia interferir na posse e na propriedade.

[...] aquele principado deve ter um cuidado solícito de seus súditos, aos quais, de direito, não pode privar dos seus bens, direitos e liberdades, embora possa exigir deles o que precisa, para fazer frente às suas necessidades, do mesmo modo que os mercenários e o estipendiário podem exigir daqueles a quem servem o que precisam para fazer frente às suas necessidades (1999d, p. 183).

Ockham admite que o papa é passível de controle e julgamento. Nesse aspecto, ele chega próximo ao moderno princípio da igualdade. O sumo pontífice, como afirmado anteriormente, deve ter seu poder delimitado com a aprovação de clérigos e leigos e pode ser julgado pelos excessos que eventualmente cometer enquanto agir na condição de representante maior da igreja. ${ }^{19}$ Quando o papa é acusado de heresia ou de um delito notório, na ausência de uma autoridade superior - e aqui se emprega autoridade no sentido de cargo ou função -, é perfeitamente lícito recorrer a um juízo subalterno. ${ }^{20}$ Assim, vislumbra-se um esboço da separação dos poderes.

\section{CONSIDERAÇÕES FINAIS}

Guilherme de Ockham é um importante nome da passagem do pensamento medieval para o pensamento moderno. Seu jusnaturalismo difere daquele dos demais nomes da escolástica, sobretudo em virtude da forma em que antevê a sombra do individualismo que marcaria a doutrina política consolidada séculos mais tarde. Para um clérigo na Idade Média, suas posições sobre razão, liberdade, origem e respeito à propriedade, limites do poder dos governantes, igualdade, sobretudo no contexto em que foram escritas, são muito avançadas.

A transição do jusnaturalismo teológico para o secular se torna mais facilmente visível e inteligível a partir da leitura dos trabalhos do Venerabilis Inceptor. Obviamente, sua obra deve ser lida com todo o cuidado e levando-se em consideração os fatos históricos que a antecederam, sucederam e, principalmente, os fatos coevos. No entanto, Guilherme de Ockham construiu indubitavelmente uma doutrina que antecede os principais nomes do liberalismo clássico no que diz respeito aos elementos que constituem os pilares fundamentais dos direitos humanos do porvir - liberdade, igualdade, propriedade.

Deve-se reconhecer, igualmente, a presença de elementos típicos das Constituições modernas nos escritos de Ockham: o poder exercido em proveito dos súditos (cidadãos); a legitimidade popular; a responsabilidade do governante; e a necessidade de garantias contra o exercício arbitrário do poder.

\footnotetext{
19 “[...] o papa ou aquele que age no lugar do papa, que se tornou herético, não faz parte, nem do número, nem merece pertencer à comunidade dos fiéis. Logo, não é o líder dos fiéis e, por conseguinte, não é um papa verdadeiro e, portanto, pode ser acusado e julgado pelo ser humano" (Sobre o poder dos imperadores e dos papas, cap. XXVIII, in fine).

${ }^{20}$ Cf. Cap. VIII do Livro VI do Tratado contra Benedito (OCKHAM, 1999a).
} 


\title{
NATURAL LAW IN WILLIAM OF OCKHAM THOUGHT
}

\begin{abstract}
The most distant basic principles of natural law were established in the Ancient Rome, when this doctrine has served as an instrument of power legitimation. In the Middle Age, philosophers used the jus naturale and adapted it in the context of dispute between the pope and the secular governments. This article analyses the political works of William of Ockham (1285? -1347) - one of the main writers of the late scholasticism - and his particular view about the natural law. His ideas were very advanced for his epoch - mainly those ones about reason, liberty, equality, property and power legitimation - and are a useful tool to comprehend the transition from theological to secular jusnaturalism. Once this article could not encompass the whole oeuvre of William of Ockham, the analysis focuses on his last political work: De imperatorum et pontificum potestate (On the power of emperors and popes).
\end{abstract}

Keywords: Natural Law; William of Ockham; fundamental rights; policy; power.

\section{REFERÊNCIAS BIBLIOGRÁFICAS}

AQUINO, Tomás de. Suma teológica - Tratado sobre a lei. In: MORRIS, Clarence (Org.). Os grandes filósofos do direito: leituras escolhidas em direito. São Paulo: Martins Fontes, 2002.

BENÍTEZ, Francisco Carpintero. Historia del derecho natural: un ensayo. México: Universidad Nacional Autónoma de México (UNAM); Instituto de Investigaciones Jurídicas, 1999.

BLOCH, Ernst. Derecho natural y dignidad humana. Trad. Felipe González Vicen. Madrid, Aguilar, 1980.

BOBBIO, Norberto. Locke e o direito natural. Brasília: UNB, 1997.

O positivismo jurídico: lições de filosofia do direito. Trad. Marcio Pugliese; Edson Bini; Carlos E. Rodríguez. São Paulo: Ícone, 1995.

BODIN, Jean. Los seis libros de la República. 3. ed. Madrid: Tecnos, 2000.

BONAVIDES, Paulo. Teoria do Estado. São Paulo: Saraiva, 1967.

CASSIRER, Ernst. O mito do Estado. São Paulo: Códex, 2003.

COURTENAY, William J. Ockham and ockhamism: studies in the dissemination and impact of his thought. Leiden; Boston: Brill, 2008.

Cuerpo del derecho civil romano (T. I - Instituta-Digesto, Primera, Segunda y Tercera partes). Traductor y compilador: Ildelfonso García del Corral. Jaime Molinas Editor: Barcelona, 1889.

DEL VECCHIO, Jorge. Persona, Estado y Derecho. Madrid: Instituto de Estudios Políticos, 1957.

ERIM, Ismail Nihat. Le positivisme juridique et le droit international. Paris: Recueil Sirey, 1939.

FORRESTER, Duncan B. Martín Lutero y Juan Calvino. In: STRAUSS, Leo; CROPSEY, Joseph vol.10, n. 01, Rio de Janeiro, 2017.pp. 63-81 
(compiladores). Historia de la filosofía política. México: Fondo de Cultura Económica, 1993, p. 305-339.

GILSON, Etienne. A filosofia na Idade Média. São Paulo: Martins Fontes, 1995.

GROTIUS, Hugo. The rights of war and peace including the law of nature and of nations. M. Walter Dunne Publisher: Washington; London, 1901.

GHISALBERTI, Alessandro. Guilherme de Ockham. Porto Alecre: EDIPUCRS, 1997.

HEERS, Jacques. O Ocidente nos séculos XIV e XV: aspectos econômicos e sociais. São Paulo: Pioneira; EDUSP, 1981.

HOBBES DE MALMESBURY, Thomas. Leviatã ou matéria, forma e poder de um Estado eclesiástico e civil. In: Os pensadores: Hobbes. São Paulo: Nova Cultural, 2000. p. 24-492.

JELLINEK, Georg. Teoría general del Estado. Trad. Fernando de los Ríos. México: Fondo de Cultura Económica, 2000.

KELSEN, Hans. Teoria geral do direito e do Estado. 3. ed. São Paulo: Martins Fontes, 1998.

KRITSCH, Raquel. Soberania: a construção de um conceito. São Paulo: Humanitas (FFLCH/USP); IMESP (Imprensa Oficial do Estado de São Paulo), 2002.

LOCKE, John. Dois tratados sobre o governo civil. São Paulo: Martins Fontes, 1998.

MCGRADE, Arthur Stephen. The political thought of William of Ockham: personal and institutional principles. Cambridge: Cambridge University Press, 1974.

MOSCA, Gaetano. História das doutrinas políticas desde a antiguidade: completada por Gaston Bouthol: as doutrinas políticas desde 1914. 6. ed. Rio de Janeiro: Guanabara, 1987.

MOURA, D. Odilão. A doutrina do direito natural em Tomás de Aquino. In: DE BONI, Luis Alberto (Org.). Idade Média: ética e política. 2. ed. Porto Alegre: EDIPUCRS, 1996. p. 219-231.

NUNES, Paulo Henrique Faria. A importância do pensamento hierocrático na consolidação da noção de soberania. Cuestiones constitucionales: Revista mexicana de derecho constitucional. Ciudad de México, n. 12, p. 159-186, enero-junio 2005.

OCKHAM, Guilherme de. Pode um príncipe. Oito questões sobre o poder do papa. Porto Alegre: EDIPUCRS; USF, 2002.

Tratado contra Benedito - Livro VI. In: Guilherme de Ockham: obras políticas. Porto Alegre: EDIPUCRS; USF, 1999, p 17-71. 73-141.

Pode um príncipe. In: Guilherme de Ockham: obras políticas. Porto Alegre: EDIPUCRS; USF, 1999, p

Consulta sobre uma questão matrimonial. In: Guilherme de Ockham: obras políticas. Porto Alegre: EDIPUCRS; USF, 1999, p 143-162.

Sobre o poder dos imperadores e dos papas. In: Guilherme de Ockham: obras políticas. Porto Alegre: EDIPUCRS; USF, 1999, p 163-254.

Brevilóquio sobre o principado tirânico. São Paulo: Vozes, 1988. 
Seleção de obras. In: Os pensadores: Tomás de Aquino, Dante, Duns Scot, Ockham. 2. ed. São Paulo: Abril Cultural, 1979.p. 344-410.

REALE, Miguel. Teoria do direito e do Estado. 5. ed. São Paulo: Saraiva, 2000.

RUSSELL, Bertrand. História do pensamento ocidental: a aventura das idéias dos pré-socráticos a Wittgenstein. Rio de Janeiro: Ediouro, 2002.

SKINNER, Quentin. Visions of politics: Reinassance virtues (v. II). Cambridge: Cambridge University Press, 2002.

As fundações do pensamento político moderno. São Paulo: Companhia das Letras, 1996.

SOUZA, José Antônio de Camargo Rodrigues de. Introdução (Sobre o poder dos imperadores e dos papas). In: OCKHAM, Guilherme de. Obras políticas. Porto Alegre: EDIPUCRS/USF, 1999, p. 165-169.

STRAUSS, Leo. Natural right and history. 7. ed. Chicago: University of Chicago Press, 1971.

VIER, Raimundo. Guilherme de Ockham: filósofo e teólogo franciscano. In: GARCIA, Antônio (Org.). Estudos de filosofia medieval: a obra de Raimundo Vier. Petrópolis; São Paulo: Vozes; Instituto Franciscano de Antropologia - Universidade São Francisco, 1997.p. 135-159.

Ockham e os tempos modernos. In: GARCIA, Antônio (Org.). Estudos de filosofia medieval: a obra de Raimundo Vier. Petrópolis; São Paulo: Vozes; Instituto Franciscano de Antropologia - Universidade São Francisco, 1997.p. 256-303.

WECKMANN, Luis. El pensamiento político medieval y los orígenes del derecho internacional. 2. ed. México: Fondo de Cultura Económica, 1993.

Trabalho enviado em 17 de junho de 2016.

Aceito em 14 de setembro de 2016. 